\title{
Milton's Selfie
}

\section{A Speculative Flight of Fancy}

\section{MIKLÓS PÉTI}

Abstract: "Fixe heere," a curious fragment by the young Milton, has been interpreted by critics as an emblematic piece expressing the poet's pervasive sense of belatedness. In my "speculative flight of fancy," I propose a different reading, one that finds a general sense of anticipation and adventure in Milton's couplet.

"Fixe heere yee overdaled sphears That wing the restless foote of time."

(John Milton)

Milton, like his contemporary Rembrandt, was a master of the self-portrait. Coleridge famously suggested that he "attract[ed] all things and forms to himself, into the unity of his own grand Ideal" (Leonard 2:89), and the series of stylised self-representations underpinning his work seem to testify to this talent eloquently. Whether in verse or prose, whether confiding to a friend or declaiming publicly, whether in English, Latin, or Greek, Milton always finds time to portray himself, often explicitly but sometimes only indirectly or by the merest puzzling hints. Who would not wonder whether Milton identifies more with L'Allegro or Il Penseroso? Who would not relish, sometimes with a pinch of salt, the series of self-representations in the (Latin and English) polemical prose? Who would believe the invocations of Paradise Lost, or the character of Samson, the richer if completely dissociated from the figure of Milton? The list could go on endlessly, but the significance of Milton's images of himself is apparent in the fact that both critics advocating Milton's "unchanging mind" and those believing in his "intellectual development" 


\section{MIKLÓS PÉTI}

make ample use of them (Le Comte and Shawcross are two famous examples representing these two positions). Yet the question comes up: should we take every attempt at self-presentation as part of the series of significant and memorable self-portraits?

The lines "Fixe heere yee overdaled sphears / That wing the restless foote of time" were first discovered and published in the "Introduction" to Milton's Commonplace Book, by Alfred J. Horwood. They are in Milton's hand on the back of a letter from Henry Lawes (written probably around April 1638) notifying Milton of his enclosed passport (a letter from the Lord Warden of the Cinque Ports). The letter (now in the British Library, Add MS 36354, f. 1v) is in rather bad condition having apparently been used, according to Horwood "as blotting paper in the course of making entries" in the Commonplace Book (xvi). In the lines in question, the meaningless "overdaled" is amended to "overdated" by most editors, antedating the word's first occurrence (also by Milton) in the $O E D$ (s.v. "overdated"). According to the editors of the Columbia edition, the couplet "may be a fragment of a larger intended poem" (Milton, The Works 18:356), and Barbara Lewalski and Estelle Haan concur: "this enigmatic pair of lines was possibly the start of a poem, apparently never finished" (Milton, The Complete Works cxlvii). What complicates the picture is that they are also "undated" and "their context is unclear" (Corns 122).

Since we have no knowledge of the lines' provenance, purpose, or use, critics have largely had to fall back on speculation. As a consequence, possible dates for the couplet slightly vary according to its interpretation. Willa McClung Evans finds in Milton's lines echoes of Eternity's song in Thomas Carew's masque Coelum Britannicum (set to music and the part of Eternity played by Lawes in 1634), and conjectures that "in the midst of packing his trunks and preparing his affairs for a year or more of foreign travel" the busy young Milton must have felt under time pressure and expressed with these lines the wish for some breathing space (149-151). ${ }^{1}$ Mother Mary Christopher Pecheux, by contrast, finds the fragment informed by the iconography of kairos (Latin occasio), citing both ancient and early modern sources (visual as well as verbal) for the strange creature with winged feet, and even identifying some artworks, including a choir screen in the Basilica of Torcello representing

1 The lines in Carew's masque are: "Be fix'd your rapid Orbes, that beare / The changing seasons of the yeare / On your swift wings, and see the old / Decrepit Spheares growne darke and cold" (Carew 259). Alternatively, Evans proposes, the news of "Carew's sudden death [in] that May of 1638," presumably reaching Milton at around the time of his travel, might have prompted this idiosyncratic recollection of Eternity's song (152). This is, however, clearly wrong, since Carew died in March 1640; could Evans have thought of his mother, Alice? Cf. Nixon. 
Time mounted on wheels, as Milton's possible source (205). She argues that the origin of the lines might be Milton's experience of this Venetian piece- or they could perhaps be a quick rendition of the $12^{\text {th }}$ stanza of Antonio Francini's tributary ode to Milton, which the poet must have heard in Venice, and which he later prefixed to the 1645 poems (206-207). ${ }^{2}$ At any rate, Pecheux dates the fragment firmly during the 15 months of Milton's stay abroad: "what my imagination refuses to conjure up," she confesses, "is Milton in his study in England just happening to write on a stray piece of paper which there was no reason for him to have immediately at hand" (208). John Kerrigan, while acknowledging Pecheux's insight concerning the iconography of the lines, puts them into a different context. Focusing on Milton's Nightingale sonnet and reflecting on how the poet's significant anxiety, a sense of personal belatedness and unused talent, changes through his oeuvre, he singles out the two lines as emblematic of the "pressure of occasion" the Italian journey presented. Kerrigan argues that the lines “catch Milton's sense that he must surely be younger than he is, but are precipitated by an alarm that, as he begins another preparation, he might already have missed his time." Accordingly, he interprets "overdated" (against the OED's “outdated; obsolete") as belated (113). Although Kerrigan does not identify an approximate date for the lines, from this point it can be inferred that he would probably put them before the start of Milton's continental journey. More recently, Nicholas McDowell has made the same case more positively: "In April 1638 , just before he left for Italy, Milton jotted down two lines on the back of the letter from Lawes which enclosed his passport." Following Kerrigan, McDowell finds in the couplet anxiety about belatedness, "the obsession with the poet's time," but also an acknowledgement of indebtedness to Lawes yet untainted by Milton's later, more ambiguous attitude to the cavalier songwriter (253-254).

To add to the line of speculations, I would propose yet another interpretation drawing on, but also going beyond, the insights cited above. Undoubtedly influenced by the iconography of kairos (either through the recollection of Carew's masque or from some other source), Milton's lines seem to steer clear from any of the concrete artworks (or occasions) Pecheux mentions (cf. the claim by Campbell and Corns that "he had no particular interest in the visual arts" [103]). It is also remarkable that they are free from any conscious expression of belatedness when read completely

2 The text of Francini's stanza is the following: "Non batta il Tempo l'ale, / Fermisi immoto, e in un fermin si gl'anni, / Che di virtù immortale / Scorron di troppo ingiuriosi a i danni; / Che s'opre dogne di Poema o storia / Furon gia, l'hai presenti alla memoria" (Fletcher 1:220). 


\section{MIKLÓS PÉTI}

out of context - after all, it is the spheres that are overdated, not the speaker. Indeed, the idea of belatedness seems to be created by critics' efforts to contextualise these lines in Milton's oeuvre, rather than in his life; such interpretations read the couplet in the light of Doctor Faustus's plea: "Stand still, you ever-moving spheres of heaven, / That time may cease, and midnight never come!" (scene 14, 11. 65-66). But Milton, at the age of 29, is certainly not expecting to "have one bare hour to live;" instead, he is probably eager to "settle [his] studies . . and begin / To sound the depth of that [he] will profess" (scene 1, ll. 1-2). What greater occasion for this than the continental tour in which he (and his family) has invested both materially and intellectually; which will give him a chance to break away from home; and for which he has just received official permission, one, furthermore that will allow him to visit Rome, a city forbidden to most English travellers at this time, but which, for Milton, was associated primarily with the culture of classical antiquity (Evans 150; Milton, The Complete Prose 1:338)?

The lines, therefore, seem to me to register a heightened sense of occasion, not without some earnest excitement. They reflect Milton's instant exhilarated reaction to the removal of the last obstacle before his tour: well-packed and well-attended, the young gentleman is now ready to depart, let time stand still for a moment to witness this thrill. Naturally, the poet's precocious knowledge about time's swift-footedness appears in the course of the couplet, but that does not seem to be more than a formulaic afterthought. The imperative "Fixe heere" is what is in strong focus here: because, for once, he will not stop for the World, the young Milton wants the World to stop for him. This sentiment might also contain a modicum of self-satisfaction: after producing a masque performed with great success and publishing a pastoral elegy unrivalled by his contemporaries, Milton might feel that he is about to reap the well-deserved reward of his labours. It is only natural that such emotions should be prompted by a letter from a fellow artist, who worked with him on his greatest project (Comus) so far. Lawes undoubtedly did a great favour to Milton by securing him the passport, but what seems to be on Milton's mind, as he is jotting down the couplet hastily, is a sense of wonder at the fruit their collaboration is about to yield.

Granted, this reading of Milton's lines does not make them nearly as complex as the interpretations quoted above suggest (cf. Kerrigan 113). My aim is not to deny that complexity but to call attention to the possibility of a less complicated reading. Whereas Evans reads the couplet as a tribute to Lawes and/or to Carew, Pecheux sees it as an indirect record of cultural influence, and Kerrigan and McDowell find 
in it vestiges of a young artist's self-portrait, I would argue that these lines simply celebrate the present occasion, the promise of the approaching journey, which Milton captures with the image of kairos, and the discourse on time available to him and his contemporaries. As such, the couplet can somewhat anachronistically be compared to present-day selfies rather than the elaborate self-portraits of the type Rembrandt and Milton himself used to compose. Selfies celebrate the present moment and create a "disposable monument" to the subject in the here and now. They might well become profound, sophisticated, or stylised, but in contrast to self-portraits, they are not the product of a prolonged creative process (cf. Wender). Milton's "selfie" is of course different from modern-day selfies not only because of the (social) media and technology involved in the latter but also in the fact that it avoids direct self-representation. The "snapshot" or rather "soundbite" of the couplet is, however, as "deictically indexical" as any selfie and through its performative imperative does show us a "self, enacting itself" (Frosh 1621) — what is more, in dimensions fully compatible with Milton's ambitions. Selfies are expected to be shared and although we do not know what Milton did with these lines, the striking similarity of Francini's ode might suggest that at least the theme must have been on his mind through his Italian travels. ${ }^{3}$ Furthermore, the letter's placement in Milton's Commonplace Book means that, at least after the poet had lost his sight, others had easy access to it. ${ }^{4}$ Here we might also note with interest that the couplet is among the most curious of Milton's works to be posted, "grafittified," and tweeted in this our present age. ${ }^{5}$

In April 1638, after he had received his passport, Milton took note of the elated moments of preparation or departure on the nearest scrap of paper available to him. The subjective experience reflected in that note was nicely counterbalanced on the same piece of paper by Lawes's letter, a reminder of the realities and minutiae of travel. The sheet, perhaps accidentally, became the blotting paper in his Commonplace Book. Is it too much to imagine that, before 1652, Milton occasionally caught sight of and mused on this old document?

3 Thus prompting a rethinking of Pecheux's contention that it was Francini who influenced Milton (see above). On the contrary, might Francini's ode be a rendering of some version Milton's couplet? Milton, at least, does talk about "some trifles which I had in memory compos'd at under twenty or thereabout" delivered in "the private Academies of Italy" (The Works 3:235-236). Might these "trifles" have included an improvised rendering (in Latin or in Italian) of a more fresh composition?

4 On the Commonplace Book, see Hanford and Poole.

5 See, for instance, "Overdated Spheres" (lemonlustre, Flickr), "Fix here ..." (Jordan, h2g2), and "Fix Here...”(@MmiAom, Twitter), the latter, significantly, accompanied by a selfie. 


\section{MIKLÓS PÉTI}

Later in his life, could he have remembered, perhaps with melancholy, the wish to stop time and the world when composing Adam's reflection, uttered just before the start of his exile, on how at the end of "this transient World" time will "stand fixt" (PL 12.554-555)? However that may be, the letter and the couplet must have brought to his mind "what he was, [and] what is" (PL 4.25), ${ }^{6}$ as well as sombre recollection of a time in his life when, definitely not "overdated" in either sense of the word, he was quite literally setting out to fresh woods and pastures new. In 1638, as a young man preparing to embark on the adventure of a lifetime after years of study, he must have anticipated immense creative tension from the interaction of modernity and antiquity in his enterprise. After all, he was about to see and experience both one of the most "overdated" and one of the most modern cultures of Europe; in the light of this venture, the world he was about to leave (which included to a large extent the solid stuff of his studies as well as his earlier works) might also have seemed quaintly "overdated." His possession of an already vast knowledge about the world of antiquity and now the opportunity to put that knowledge to modern use put him far ahead of most of his contemporaries, indeed, to a vantage point from where it is possible to reflect on how the "overdated spheres ... wing the restless foote of time." As he was jotting down "Fixe heere," Milton might well have felt the world was all before him.

\section{Works Gited}

Campbell, Gordon, and Thomas N. Corns. John Milton: Life, Work, and Thought.

Oxford: Oxford University Press, 2008.

Carew, Thomas. Poems. London, 1640.

Corns, Thomas N., ed. The Milton Encyclopedia. New Haven: Yale University Press, 2012. Evans, Willa McClung. Henry Lawes. Musician and Friend of Poets. New York: Kraus, 1966. Fletcher, Harris Francis, ed. John Milton's Complete Poetical Works Reproduced in Photographic Facsimile. Urbana: The University of Illionois Press, 1943.

Frosh, Paul. "The Gestural Image: The Selfie, Photography Theory, and Kinesthetic Sociability." International fournal of Communication 9 (2015): 1607-1628.

Hanford, James Holly. "The Chronology of Milton's Private Studies.” PMLA 36.2 (1921): 251-314.

6 Cf. his musings on "an age too late" together with the poet's "Years" in $P L(9.44-45)$. 


\section{MILTON'S SELFIE}

Horwood, Alfred J., ed. Fohn Milton's Commonplace Book. London: The Camden Society, 1876.

Jordan [Researcher U187234]. "Fix here . ." h2g2, n. d. Web. 11 Jan 2019.

Kerrigan, John. "Milton and the Nightingale." Essays in Criticism 42.2 (1992): 107-122.

Le Comte, Edward. Milton's Unchanging Mind. New York: Associated Faculty Pr. Inc, 1973.

lemonlustre [Maria T. Brodine]. "Overdated Spheres." Flickr, 8 Dec 2005. Web. 11 Jan 2019.

Leonard, John. Faithful Labourers. A Reception History of Paradise Lost 1667-1970. 2 vols. Oxford: Oxford University Press, 2012.

Marlowe, Christopher. The Complete Plays. Eds. Romany, Frank, and Robert Lindsay. London: Penguin, 2003.

McDowell, Nicholas. "Dante and the Distraction of Lyric in Milton's 'To My Friend Mr Henry Lawes."' The Review of English Studies New Series, 59.239 (2008): 232-254.

Milton, John. The Complete Prose Works of John Milton. Gen. ed. Wolfe, Don M. New Haven: Yale University Press, 1953-1982.

- The Complete Works of John Milton: Volume III: The Shorter Poems. Eds. Kiefer Lewalski, Barbara, and Estelle Haan. Oxford: Oxford University Press, 2012.

- The Works of John Milton. Eds. Patterson, F. A. et al. New York: Columbia University Press, 1931-1938.

@,MymiAom [Mymi Aom-am]. "Fix Here ...” Twitter, 11 Sep 2014, 6.36 am. Web. 11 Jan 2019.

Nixon, Scott. "Carew, Thomas (1594/5-1640)." Oxford Dictionary of National Biography. Oxford University Press, 2004. Web. 11 Jan 2019.

Pecheux, Mother M. Christopher. "Milton and Kairos." Milton Studies 12 (1978): 197-211. Poole, William. "The Genres of Milton's Commonplace Book." In The Oxford Handbook of Milton. Eds. McDowell, Nicholas, and Nigel Smith. Oxford: Oxford University Press, 2009. 367-381.

Shawcross, John T. The Development of Milton's Thought. Pittsburgh: Duquesne University Press, 2008.

Wender, Jessie. "Seeing Themselves: Photographers' Self-Portraits." The New Yorker. 20 Feb 2014. Web. 11 Jan 2019. 


\section{MIKLÓS PÉTI}

\section{Contributor Details}

Miklós Péti is associate professor of English literature at Károli Gáspár Unversity, Budapest, Hungary. His research focuses on classical influences on Milton's poetry and Milton's Hungarian reception. His prose translation of Paradise Regained was published in a bilingual edition by the Jelenkor Publishing House in 2019. 